\title{
THE GROWTH AND CHARACTERIZATION OF GaInAsSb AND AIGaAsSb ON GaSb BY METAL- ORGANIC CHEMICAL VAPOR DEPOSITION
}

R. M. Biefeld, J. G. Cederberg, G. M. Peake, and S. R. Kurtz, Sandia National Laboratories

Abstract

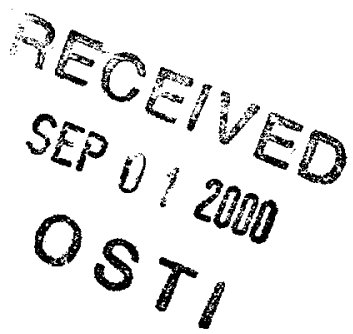

The growth conditions for GaInAsSb and AlGaAsSb using metal-organic chemical vapor deposition in'an high speed rotating disk reactor are described. Trimethylindium, triethylgallium, arsine, and trimethylantimony were used as precursors for the growth of GaInAsSb. Triethylgallium, ethyldimethylamine alane, triethylantimony, and arsine were the precursors used for the growth of $\mathrm{AlGaAsSb}$. These materials were doped both $\mathrm{n}$ - and p-type using a mixture of diethyltellurium and diethylzinc as sources. An optimum growth temperature of $520^{\circ} \mathrm{C}$ was determined for the growth of GaInAsSb. Growth at this temperature yielded a root mean square (rms) surface roughness of $0.142 \mathrm{~nm}$. $\mathrm{AlGaAsSb}$ could be grown over the range of 500 to $600^{\circ} \mathrm{C}$ with somewhat rougher surfaces (rms>0.7 nm). The photoluminescence was found to correlate with surface roughness, increasing with smoother surfaces. : AlGaAsSb mesa isolated diodes were prepared and characterized. These diodes showed good currentvoltage characteristics with breakdown voltages greater than -6 volts. 


\section{Introduction}

Recently there has been a renewed interest in the use of GaSb-based materials for thermophotovoltaic power generation $[1,2,3]$. We are investigating thermophotovoltaic (TPV) materials and devices for use in converting infrared radiation by means of a semiconductor photodiode to produce electricity. The potentially high power density, quiet operation, and low maintenance of these devices make them of interest for a variety of uses including vehicles, portable power sources, and remote dwellings [2,3]. Practical and cost effective deployment of such systems poses several engineering and materials science challenges. Large arrays of these TPV devices will be needed to generate enough power for some applications. One approach to achieve this power is to use series connected photovoltaic cells in an integrated module $[2,3]$. This approach requires that the individual cells be electrically isolated. This can be achieved using either a semi-insulating substrate or an isolation diode if a conducting substrate is used. In order to convert thermal radiation efficiently to electricity one must use a semiconductor with a band gap energy close to the energy of the infrared radiation being emitted by the source. We have chosen to develop photodiodes using GaInAsSb quaternaries lattice matched to GaSb substrates. These materials have a bandgap of approximately $0.5 \mathrm{eV}(2500 \mathrm{~nm})$ which closely matches the spectral emittance of a blackbody radiator at a temperature of $1000^{\circ} \mathrm{C}$. Since monolithic interconnected modules offer compelling advantages for the large-scale deployment of TPV systems, we are investigating the use of cell isolation diodes involving the growth and doping of AlGaAsSb lattice matched to GaSb substrates. Toward this end we have investigated the growth and doping of GaInAsSb and AlGaAsSb quaternaries lattice matched to GaSb using metal-organic chemical vapor deposition (MOCVD) in an Emcore D75 high-speed rotating disk reactor (RDR). We have also explored the n- and p-type doping of these materials using diethyltellurium, and diethylzinc, respectively. We will report on the growth conditions used to prepare these materials by MOCVD as well as their characterization by $\mathrm{x}$-ray diffraction, atomic force microscopy, photoluminescence, and Hall measurements. We will also present current-voltage measurements of a cell isolation diode fabricated from the AlGaAsSb material 


\section{DISCLAIMER}

This report was prepared as an account of work sponsored by an agency of the United States Government. Neither the United States Government nor any agency thereof, nor any of their employees, make any warranty, express or implied, or assumes any legal liability or responsibility for the accuracy, completeness, or usefulness of any information, apparatus, product, or process disclosed, or represents that its use would not infringe privately owned rights. Reference herein to any specific commercial product, process, or service by trade name, trademark, manufacturer, or otherwise does not necessarily constitute or imply its endorsement, recommendation, or favoring by the United States Government or any agency thereof. The views and opinions of authors expressed herein do not necessarily state or reflect those of the United States Government or any agency thereof. 


\section{DISCLAIMER}

Portions of this document may be illegible in electronic image products. Images are produced from the best available original document. 


\section{Experimental}

The GaInAsSb and AlGaAsSb investigated in this study were grown by MOCVD on not intentionally doped, or $\mathrm{Zn}$ or Te doped GaSb substrates oriented either on axis (001) or 6 degrees towards (111)B. Trimethylindium, triethylgallium, arsine, and trimethylantimony were used as precursors for the growth of GaInAsSb. Triethylgallium, ethyldimethylamine alane, triethylantimony, and $100 \%$ or $10 \%$ $\mathrm{AsH}_{3}$ in hydrogen were the precursors used for the growth of $\mathrm{AlGaAsSb}$. We optimized the growth of these materials by first examining the growth of $\mathrm{GaSb}$ under similar conditions. The optimum V/III ratio found for $\mathrm{GaSb}$ was then used as a starting point for the growth of $\mathrm{GaInSb}$ or $\mathrm{AlGaSb}$. The V/II ratios used ranged from 2 to 5 . A low V/II ratio is necessary for the growth of high quality GaInAsSb or AlGaAsSb. Due to the low vapor pressure of Sb, excess $\mathrm{Sb}$ tends to cause surface morphology defects. The optimum ratio depended primarily on growth temperature. Little or no dependence of the optimum V/III ratio was found for growth rate variation. The growth rate was linearly dependent on the amount of group III element flowing into the reactor. The $\mathrm{Ga} / \mathrm{In}$ and $\mathrm{Al} / \mathrm{Ga}$ ratios were determined by double crystal $\mathrm{x}$-ray diffraction of the respective $\mathrm{Sb}$ or As containing ternary compound. The growth of these materials was investigated over a temperature range of 500 to $600^{\circ} \mathrm{C}$ at 70 torr in an Emcore D75 high speed rotating disk reactor at a rotation speed of $1100 \mathrm{rpm}$. The carrier gas and its quantity were 15 standard liters per minute of hydrogen. Growth rates were varied from 0.25 to $1.35 \mathrm{~nm} / \mathrm{s}$ for GaInAsSb but only a growth rate of $0.65 \mathrm{~nm} / \mathrm{s}$ for $\mathrm{AlGaAsSb}$ was investigated. The dopant sources investigated were diethylzinc (DEZn) and a mixture of diethyltellurium (DETe) in hydrogen (50 ppm). The lattice matching with the substrate was determined by double crystal $\mathrm{x}$-ray diffraction using the (004) reflection. For a given group III ratio, typically the lattice matching was adjusted by changing the amount of $\mathrm{AsH}_{3}$ in the reactor.

Growth runs were monitored using in-situ reflectance to evaluate surface morphology development [4]. Sample thicknesses were measured by either using a groove technique or from analyzing the reflectance profile.

Infrared photoluminescence (PL) was measured on all samples of GaInAsSb at $300 \mathrm{~K}$ using a double-modulation, Fourier-transform infrared (FTIR) technique which provides high sensitivity, reduces sample heating, and eliminates the blackbody background from infrared emission spectra. Not all GaInAsSb layers had measurable PL. 
Room temperature Hall measurements using the Van der Pauw technique determined the majority carrier type and concentration in the AlGaAsSb or GaInAsSb layers grown on semi-insulating GaAs substrates. Contacts were formed by alloying $\operatorname{In} / \mathrm{Sn}(90: 10)$ or $\operatorname{In} / \mathrm{Zn}(95: 5)$ at 300 to $340{ }^{\circ} \mathrm{C}$ in a $\mathrm{Ar} / \mathrm{H}_{2}$ atmosphere.

Atomic force microscopy (AFM) images of selected sample surfaces were obtained using tapping mode AFM. The AFM tips were etched Si cantilevers with a nominal tip radius of 5 to $10 \mathrm{~nm}$ and sidewall angles of $10^{\circ}$ and $25^{\circ}$.

\section{Results and Discussion}

We have grown high quality $\mathrm{Ga}_{0.89} \mathrm{In}_{0.11} \mathrm{As}_{0.1} \mathrm{Sb}_{0.9}$ at $520^{\circ} \mathrm{C}$ and 70 torr using $1100 \mathrm{rpm}$ in an Emcore D75 reactor. These materials were grown using a growth rate of $1.0 \mathrm{~nm} / \mathrm{s}$ and a V/II ratio of 3.7 on a GaSb substrate misoriented by $6^{\circ}$ from the (001) towards (111) B. The TMIn/TEGa and $\mathrm{AsH}_{3}$ TMSb ratios were 0.04 and 0.12 , respectively. Under these growth conditions and when a GaSb cap was grown on top of the GaInAsSb the sample had good photoluminescence (PL) at $2.1 \mu \mathrm{m}$ (see Figure 1) and the intensities were comparable to the PL of similar samples grown by C. A. Wang $[5,6]$. The room temperature PL spectrum and the $\mathrm{x}$-ray diffraction pattern for this material are shown in Figures 1 and 2. The x-ray diffraction pattern in Figure 2 shows a GaInSb peak to the left (low theta) of the substrate peak. This peak is formed due to the presence of In on the surface after growth of the GaInAsSb layer. There are also two large peaks located on either side of the main GaInAsSb peak which are probably due to a gradation of In content throughout the GaInAsSb layer.

The GaSb capped surface of the GaInAsSb layers was generally very smooth with a root mean square (rms) roughness of 0.142 to $0.378 \mathrm{~nm}$ as determined from tapping mode AFM. Images of these two samples are shown in Figure 3. The surface shown in Figure $3 a$ is very flat while that in Figure $3 b$ indicates the presence of step bunching. These two samples were grown at slightly different temperatures: $3 \mathrm{a}$ at 520 ${ }^{\circ} \mathrm{C}$ and $3 \mathrm{~b}$ at $500{ }^{\circ} \mathrm{C}$. Similar results were found for the growth of $\mathrm{GaSb}$ with rougher surfaces being present at temperatures lower than $520^{\circ} \mathrm{C}$. The PL intensity of the step bunched surface was less than two thirds that of the flat surface samples. These morphology results are similar to those found by Wang [7]. When samples were grown under identical conditions at either temperature without a GaSb cap the surface was very rough ( $4.9 \mathrm{rms}$ ) and contained a high density of small hillocks (see Figure $3 \mathrm{c}$ ). These hillocks are due 
to In carry over in the reaction chamber. The samples with the In hillocks exhibited no measurable PL. This lack of PL is probably due to non-radiative recombination taking place on the rough surface possible at the In-rich hillocks.

We have also explored the $n$ - and p-type doping of GaInAsSb and GaSb using DEZn and a 50ppm mixture of DETe in hydrogen. Not intentionally doped GaInAsSb is p-type with a carrier concentration of 2 $x 10^{17} \mathrm{~cm}^{-3}$ and a mobility of $100 \mathrm{~cm}^{2} /$ s. We have successfully doped GaInAsSb n-type up to $8 \times 10^{18} \mathrm{~cm}^{-3}$ with a mobility of $418 \mathrm{~cm}^{2} / \mathrm{Vs}$ using DETe and p-type up to $6 \times 10^{18} \mathrm{~cm}^{-3}$ with a mobility of $70 \mathrm{~cm}^{2} / \mathrm{Vs}$ using DEZn. Not intentionally doped GaSb is p-type with a carrier concentration of $3 \times 10^{16} \mathrm{~cm}^{-3}$ and a mobility of $309 \mathrm{~cm}^{2} / \mathrm{Vs}$. GaSb can be doped n-type with DETe up to at least $3 \times 10^{18} \mathrm{~cm}^{-3}$ with a mobility of $1131 \mathrm{~cm}^{2} / \mathrm{Vs}$. P-type GaSb can be prepared using DEZn with carrier concentrations up to $3 \times 10^{19} \mathrm{~cm}^{-3}$ and mobilities of $122 \mathrm{~cm}^{2} / \mathrm{Vs}$.

We have grown good quality $\mathrm{Al}_{0.4} \mathrm{Ga}_{0.6} \mathrm{As}_{0.04} \mathrm{Sb}_{0.96}$ in an Emcore $\mathrm{D} 75$ reactor using a temperature of $550{ }^{\circ} \mathrm{C}$ at 70 torr and a rotation speed of $1100 \mathrm{rpm}$. These layers were grown using a growth rate of 0.6 $\mathrm{nm} / \mathrm{s}$, a V/III ratio of 1.2 , an EDMAA/TEGa ratio of 0.39 , and an $\mathrm{AsH}_{3} / \mathrm{TESb}$ ratio of 0.012 . Under these growth conditions the not intentionally doped AlGaAsSb had a p-type carrier concentration of $5 \times 10^{17} \mathrm{~cm}^{-3}$ with a mobility of $100 \mathrm{~cm}^{2} / \mathrm{Vs}$. The surfaces were fairly rough with $\mathrm{rms}$ between 0.7 to $1.5 \mathrm{~nm}$. The surfaces appeared to consist of very large steps as illustrated in Figure 4. We have found similar morphologies for $\mathrm{Al}_{x} \mathrm{Ga}_{1-x} \mathrm{As}_{y} \mathrm{Sb}_{1-y}$ layers for $0.0<\mathrm{x}<0.4$. We explored a variety of growth conditions as outlined in the experimental section to improve the morphology and found negligible improvement for the conditions examined.

We have successfully doped $\mathrm{Al}_{0.4} \mathrm{Ga}_{0.6} \mathrm{As}_{0.04} \mathrm{Sb}_{0.96}$ with $\mathrm{DETe}$ over a range of only 1 to $2 \times 10^{17}$ $\mathrm{cm}^{-3}$ for dopant mole fractions of $8 \times 10^{-8}$ to $3.3 \times 10^{-7}$. Attempts to dope $\mathrm{AlAs}_{0.08} \mathrm{Sb}_{0.02}$ and $\mathrm{Al}_{0.9} \mathrm{Ga}_{0.1} \mathrm{As}_{0.01} \mathrm{Sb}_{0.99}$ resulted in a maximum n-type carrier concentration of $<3 \times 10^{16} \mathrm{~cm}^{-3}$. Layers of $\mathrm{Al}_{0.4} \mathrm{Ga}_{0.6} \mathrm{As}_{0.04} \mathrm{Sb}_{0.96}$ with higher DETe mole fraction $\left(>5.0 \times 10^{-7}\right)$ were grown but these layers appear to be highly compensated with an n-type carrier concentration of $7.9 \times 10^{14} \mathrm{~cm}^{-3}$. In an attempt to explain this result we had secondary ion mass spectroscopy (SIMS) measurements carried out on a sample in which layers of AlGaAsSb and GaSb were alternated and doped to increasing levels with DETe[8]. The results of the measurement are illustrated in Figure 5. The Te doping level changes are $0.83,1.67,3.33$, and $5.00 \mathrm{x}$ 
$10^{-7}$ mole fraction from the substrate outwards. The doping levels are the same for the GaSb and AlGaAsSb layers which are grown at the same growth rate of $6.5 \mathrm{~nm} / \mathrm{s}$. As can be seen in Figure 5, the amount of Te that is incorporated into the AlGaAsSb continues to increase as the mole fraction of DETe increases. The amount of incorporated $\mathrm{Te}$ is greater for $\mathrm{AlGaAsSb}$ than it is for $\mathrm{GaSb}$ for identical gas phase mole fractions of DETe. The carrier concentration for the GaSb continues to increase while that of the AlGaAsSb dramatically decreases at a Te concentration above $5 \times 10^{19} \mathrm{~cm}^{-3}$. For lower levels, the activation of the $\mathrm{Te}$ in the $\mathrm{GaSb}$ is greater than in the AlGaAsSb. For instance, at a Te concentration of 1.5 $\times 10^{19} \mathrm{~cm}^{-3}$ the carrier concentration in the GaSb is $1 \times 10^{18} \mathrm{~cm}^{-3}$ while only being $1 \times 10^{17} \mathrm{~cm}^{-3}$ in AlGaAsSb. This might be related to the amount of oxygen in the AlGaAsSb $\left(10^{19} \mathrm{~cm}^{-3}\right)$ which is much higher than for $\mathrm{GaSb}\left(<10^{17} \mathrm{~cm}^{-3}\right)$ or it may be a solubility difference (see Figure 5).

We have prepared $\mathrm{Al}_{0.4} \mathrm{Ga}_{0.6} \mathrm{As}_{0.04} \mathrm{Sb}_{0.96}$ cell isolation diodes using the above growth and doping techniques. The current-voltage curve for one of these diodes is shown in Figure 6. This diode (5177) was grown on a GaSb substrate that was misoriented from (100) 6 degrees toward (111)B and doped p-type with $\mathrm{Zn}$. The diode structure consisted of a not intentionally doped AlGaAsSb p-type $\left(\sim 5 \times 10^{17}\right)$ base, 1230

$\mathrm{nm}$ thick, an AlGaAsSb Te-doped, n-type $\left(\sim 1 \times 10^{17} \mathrm{~cm}^{-3}\right)$ emitter, $270 \mathrm{~nm}$ thick, and a GaSb Te-doped, $\mathrm{n}$ type $\left(-2 \times 10^{18} \mathrm{~cm}^{-3}\right) 1270 \mathrm{~nm}$ cap. The substrate was metallized with Ti/Pt/Au for the p-type contact and an annular ring of $\mathrm{Pd} / \mathrm{Ge} / \mathrm{Au} / \mathrm{Ti} / \mathrm{Au}$ was used for the $\mathrm{n}$-type contact. Circular mesas were formed with an inductively coupled plasma reactive ion etch to laterally isolate the diodes. The I-V characteristics of the samples were measured with a Keithley 2410 Sourcemeter and powered by a Hewlett Packard 4140A DC Voltage Source each controlled by LabView. Current was limited in the measurement to 0.1 Amps to avoid damage to the diode structures. The diode has a reasonable breakdown voltage for this material of greater than -6 Volts and should be able to serve as a cell isolation diode in a GaInAsSb TPV cell.

\section{Summary}

We have successfully grown GaInAsSb and doped it both $n$ - and p-type. We have determined that this materials is of good optical quality exhibiting strong PL at $2.1 \mu \mathrm{m}$. The surfaces of these materials when capped with $\mathrm{GaSb}$ were very smooth with an rms roughness of $0.14 \mathrm{~nm}$. The optical quality of these materials was found to be directly correlated with the surface roughness. The PL intensity decreased as the 
surface became rougher. We have also successfully prepared AlGaAsSb and doped it both n- and p-type.

The surface of this material had an rms roughness of $>0.7 \mathrm{~nm}$ and consisted of very large steps. We have fabricated diodes from this material and demonstrated characteristics that are acceptable for the formation of cell isolation diodes for TPV cells.

\section{Acknowledgments}

The authors are grateful to $\mathrm{M}$. White and J. Bur for assistance in the preparation and characterization of these materials. This work was supported by the US DOE under Contract No. DE-AC04-94AL85000. Sandia is a multiprogram laboratory operated by Sandia Corporation, a Lockheed Martin Company, for the United States Department of Energy.

\section{References}

1. C. A. Wang, H.K. Choi, S. L. Ransom, G. W. Charache, L. R. Danielson, and E. M. DePoy, Appl. Phys. Lett. 75, 1305 (1999).

2. T. J. Couts, Renewable and Sustainable Energy Reviews, 3, 77 (1999)

3. M. W. Wanlass, J. S. Ward, K. A. Emery, M. M. Al-Jassim, K. M. Jones, and T. J. Coutts, Solar Energy Mater. and Solar Cells, 41/42 405 (1996).

4. W. Breiland, H. Ho, H. Chui, and B. Hammons, J. Crystal Growth 174 (1997) 564.

5. C. A. Wang private communication :

6. C. A. Wang, H. K. Choi, D. C. Oakley, and G. W. Charache, J. Cyrstal Growth, 195 (1998) 346.

7. C. A. Wang Appl. Phys. Lett. 76, 2077 (2000).

8. Evans East, 104 Windsor Center, Suite 101East Windsor, NJ 08520 


\section{Figure Captions}

Figure 1. The room temperature photoluminescence spectrum of a layer of $\mathrm{Ga}_{0.89} \mathrm{In}_{0.11} \mathrm{As}_{0.1} \mathrm{Sb}_{0.9}$ capped with $200 \mathrm{~nm}$ of GaSb showing emission at $2.1 \mu \mathrm{m}$.

Figure 2. The double crystal $x$-ray diffraction pattern of a layer of $\mathrm{Ga}_{0.89} \mathrm{In}_{0.11} \mathrm{As}_{0.1} \mathrm{Sb}_{0.9}$ capped with $200 \mathrm{~nm}$ of $\mathrm{GaSb}$. The most intense peak is the $\mathrm{GaSb}$ substrate peak. The theta values are relative to the substrate peak.

Figure 3. Atomic force microscopy images of GaInAsSb layers grown on (001) GaSb miscut $6^{\circ}$ toward (111)B: (a) GalnAsSb grown at $520^{\circ} \mathrm{C}$ with a $200 \mathrm{~nm}$ GaSb cap with an rms roughness of $.142 \mathrm{~nm}$; (b) GaInAsSb grown at $500^{\circ} \mathrm{C}$ with a $100 \mathrm{~nm} \mathrm{GaSb}$ cap with an rms roughness of $0.378 \mathrm{~nm}$; and (c) GaInAsSb grown at $500^{\circ} \mathrm{C}$ without any GaSb cap indicating the presence of large In-based hillocks .

Figure 4. Atomic force microscopy images of an AlGaAsSb surface with an rms roughness $>0.7 \mathrm{~nm}$.

Figure 5. Secondary ion mass spectroscopy results of an $\mathrm{AlGaAsSb} / \mathrm{GaSb}$ multilayer structure doped with increasing levels of Te. The Te doping level changes are $0.83,1.67,3.33$, and $5.00 \times 10^{-7}$ mole fraction from the substrate outwards. The doping levels are the same for the GaSb and AlGaAsSb layers which are grown at the same growth rate. 


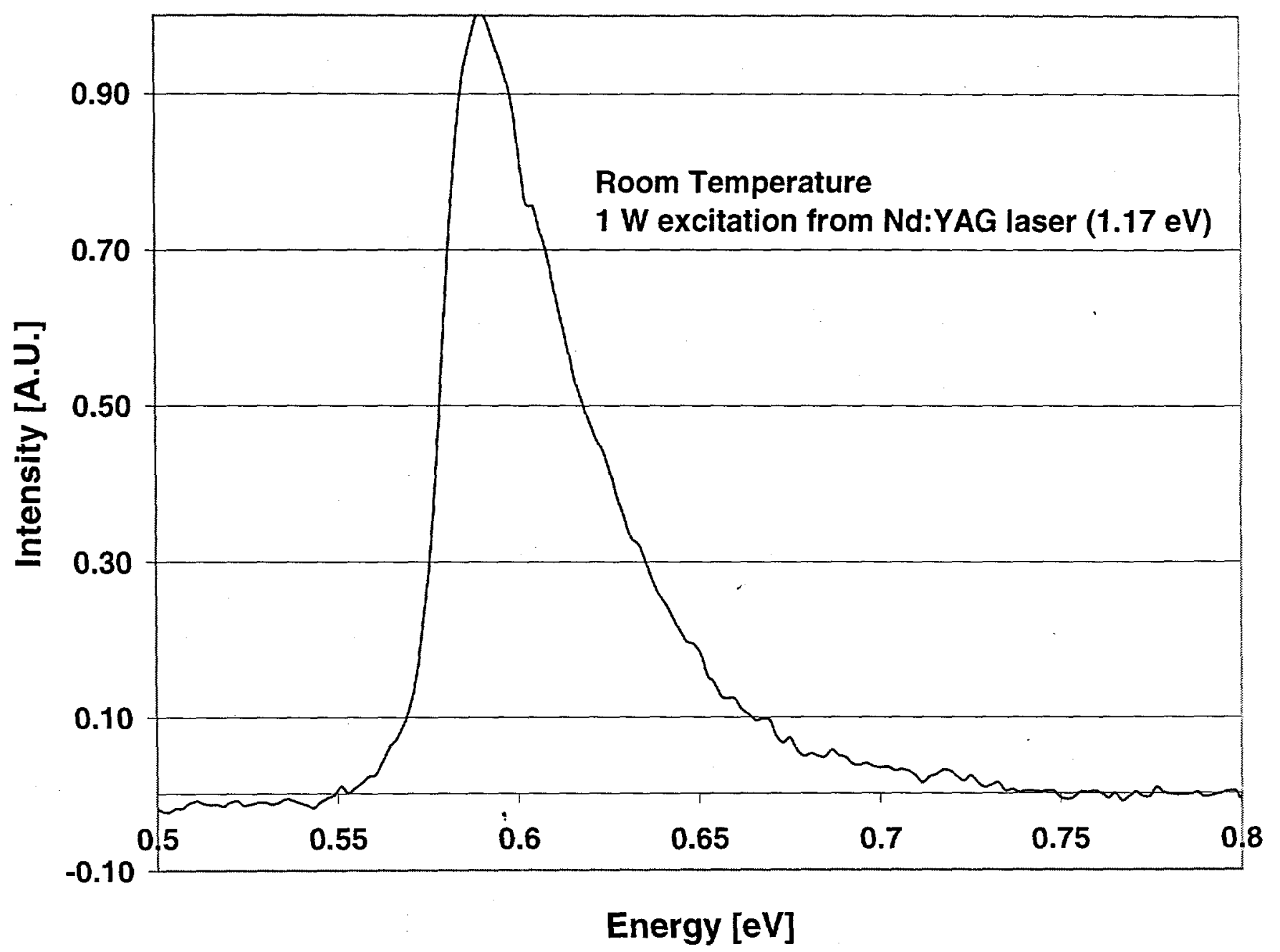




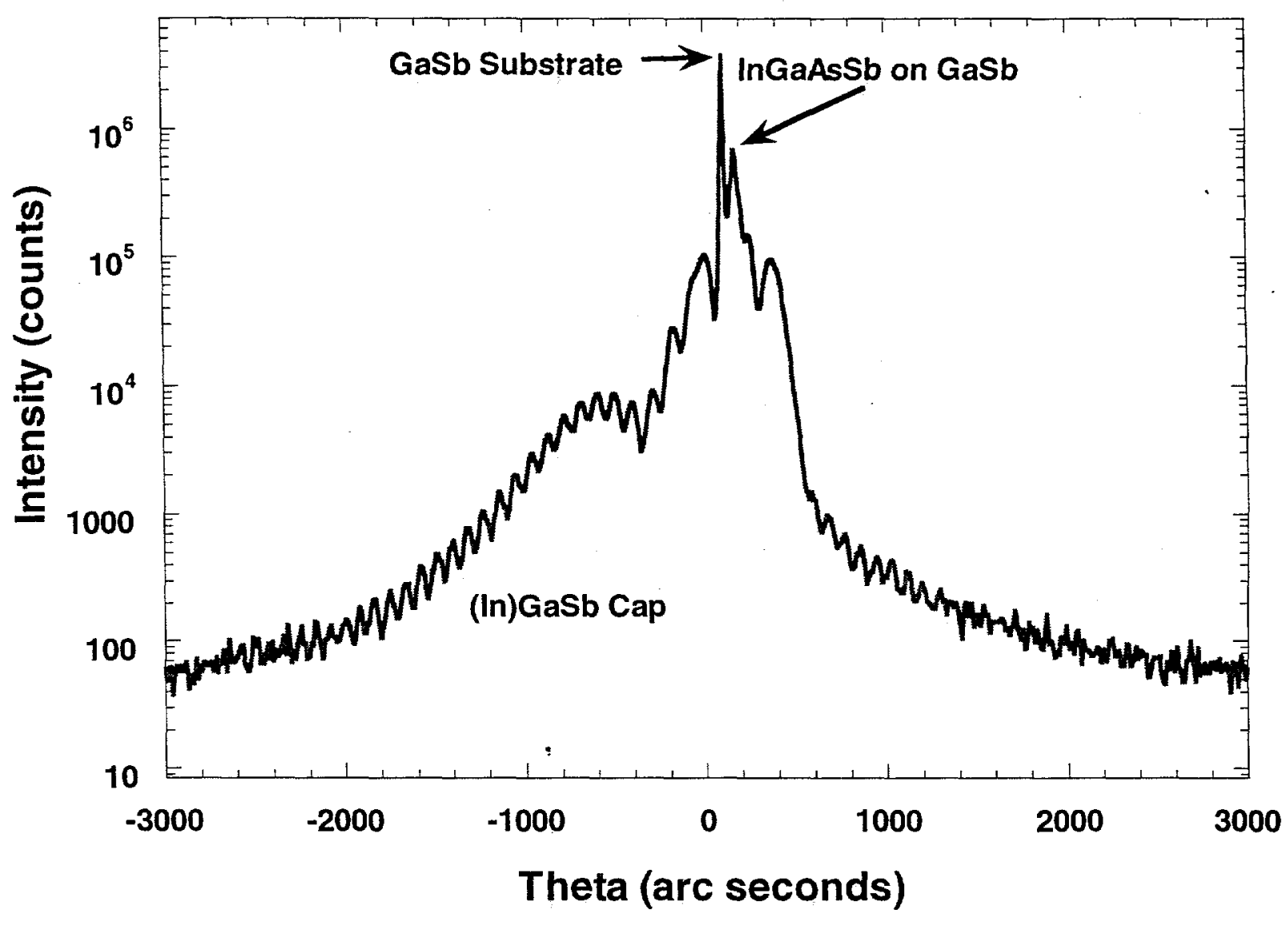




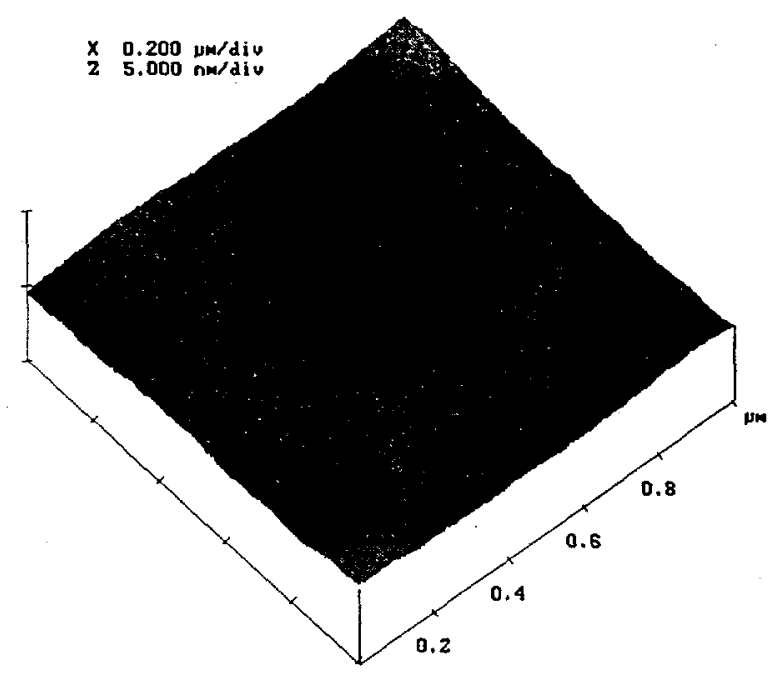

Figure $3 a$

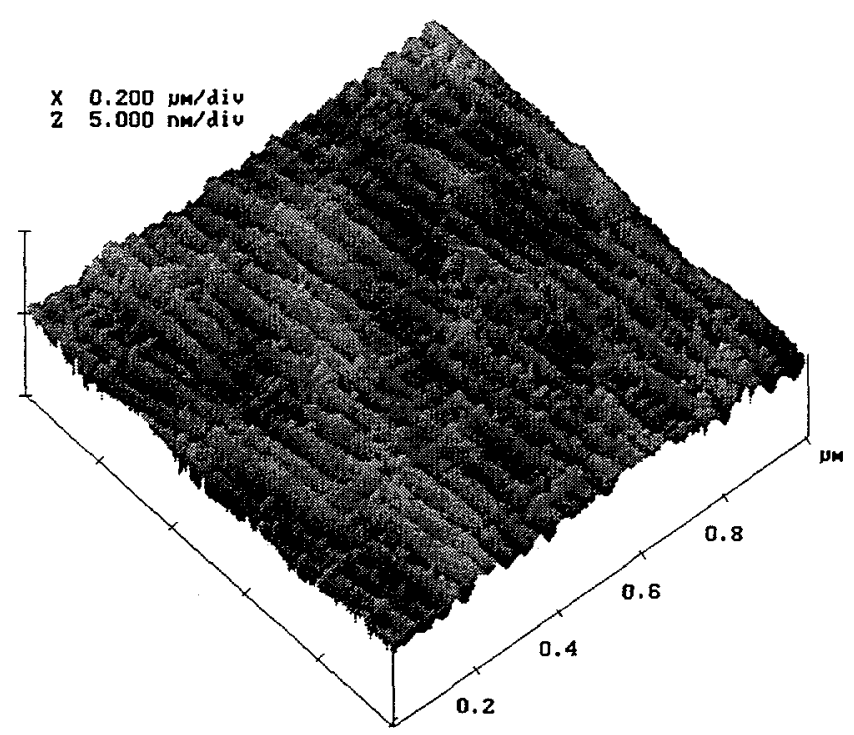

Figure $3 b$ 
Figure $3 \mathrm{c}$

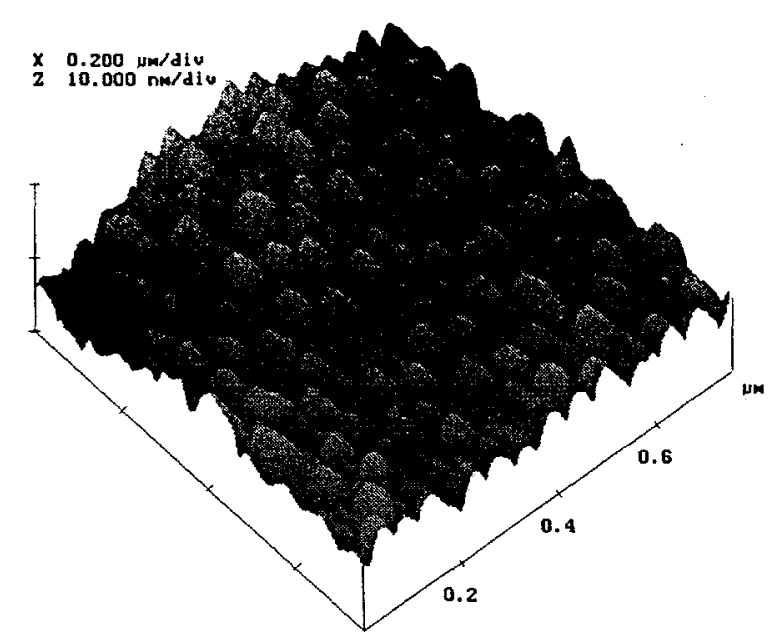




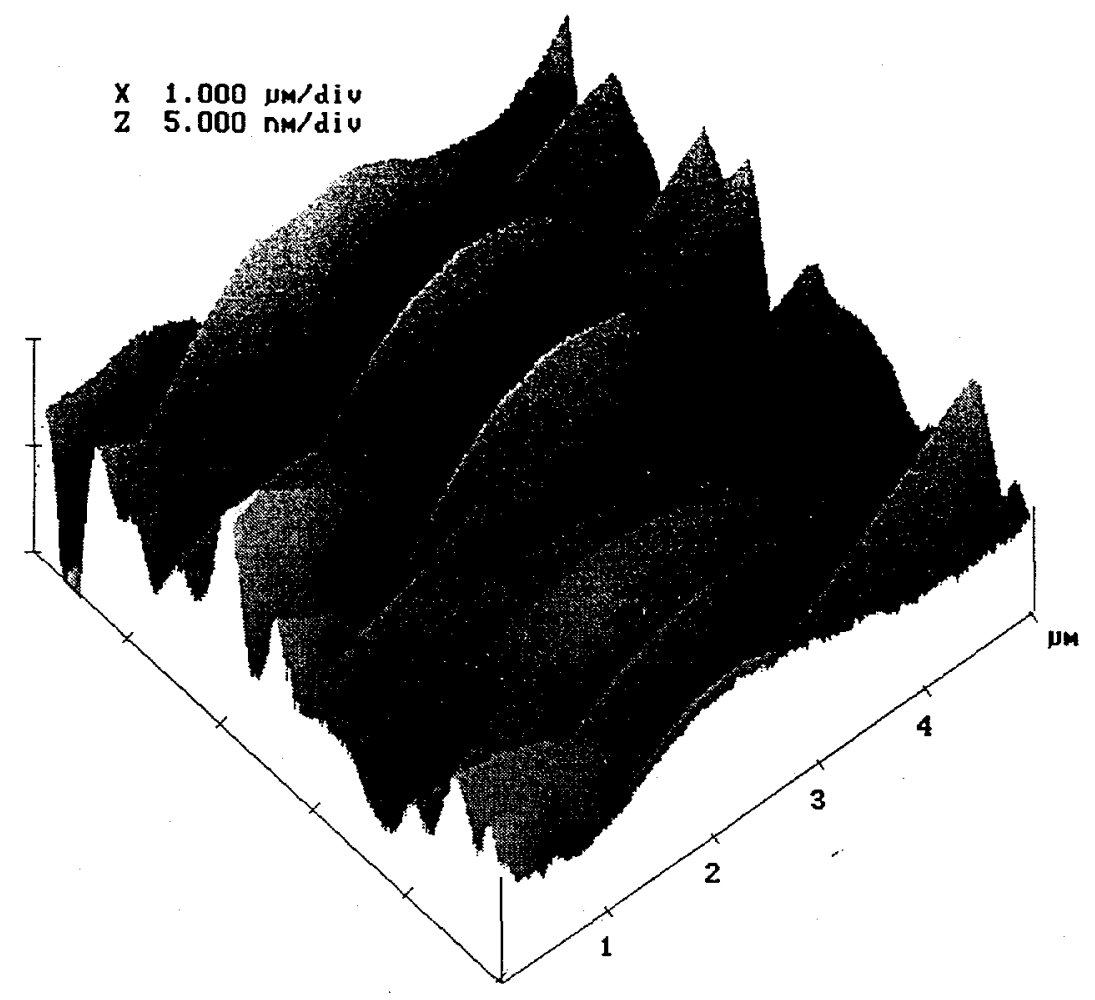

Figure 4. AFM of AlGaAsSb surface. 


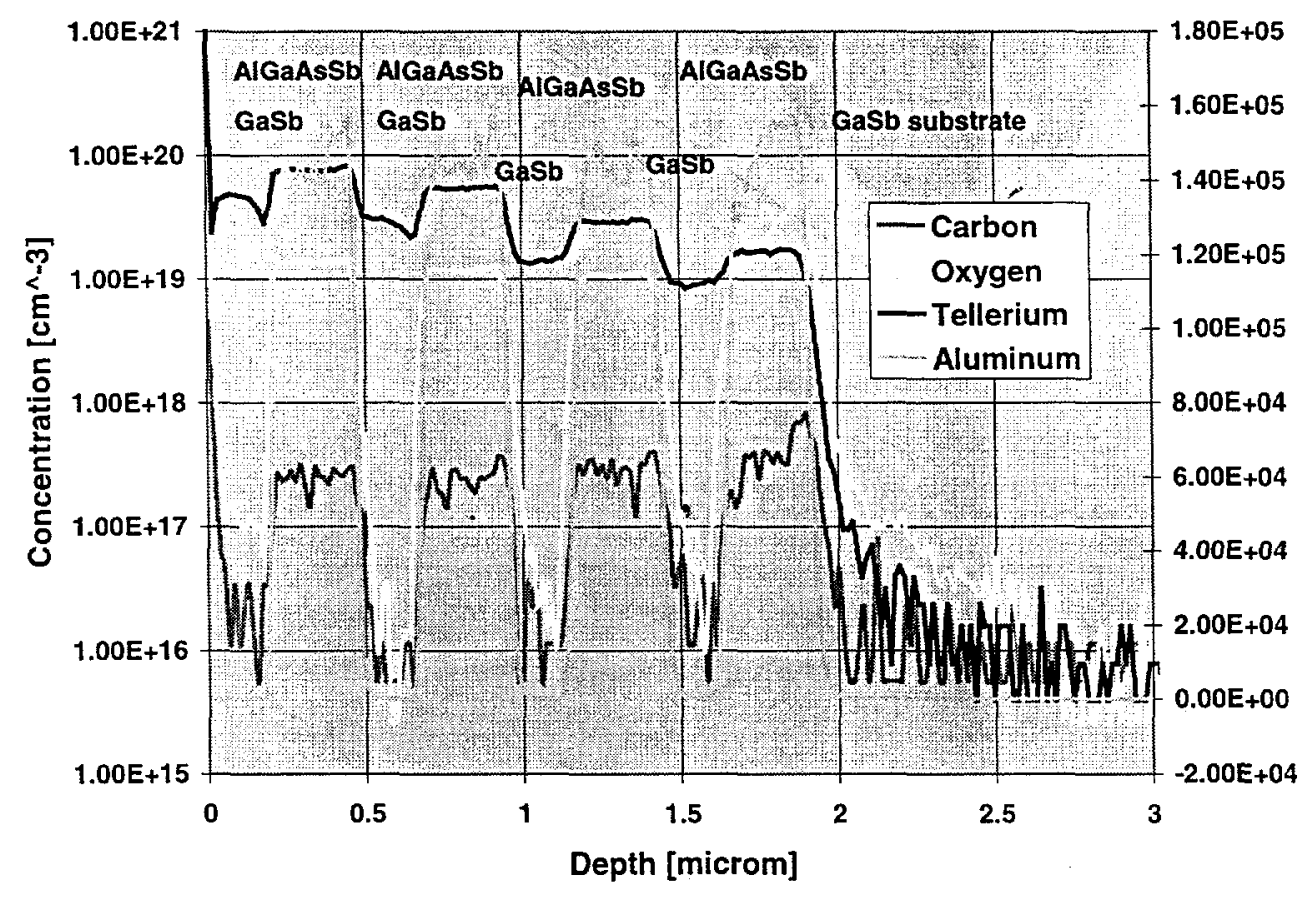

Figure 5 SIMS Te doping results 


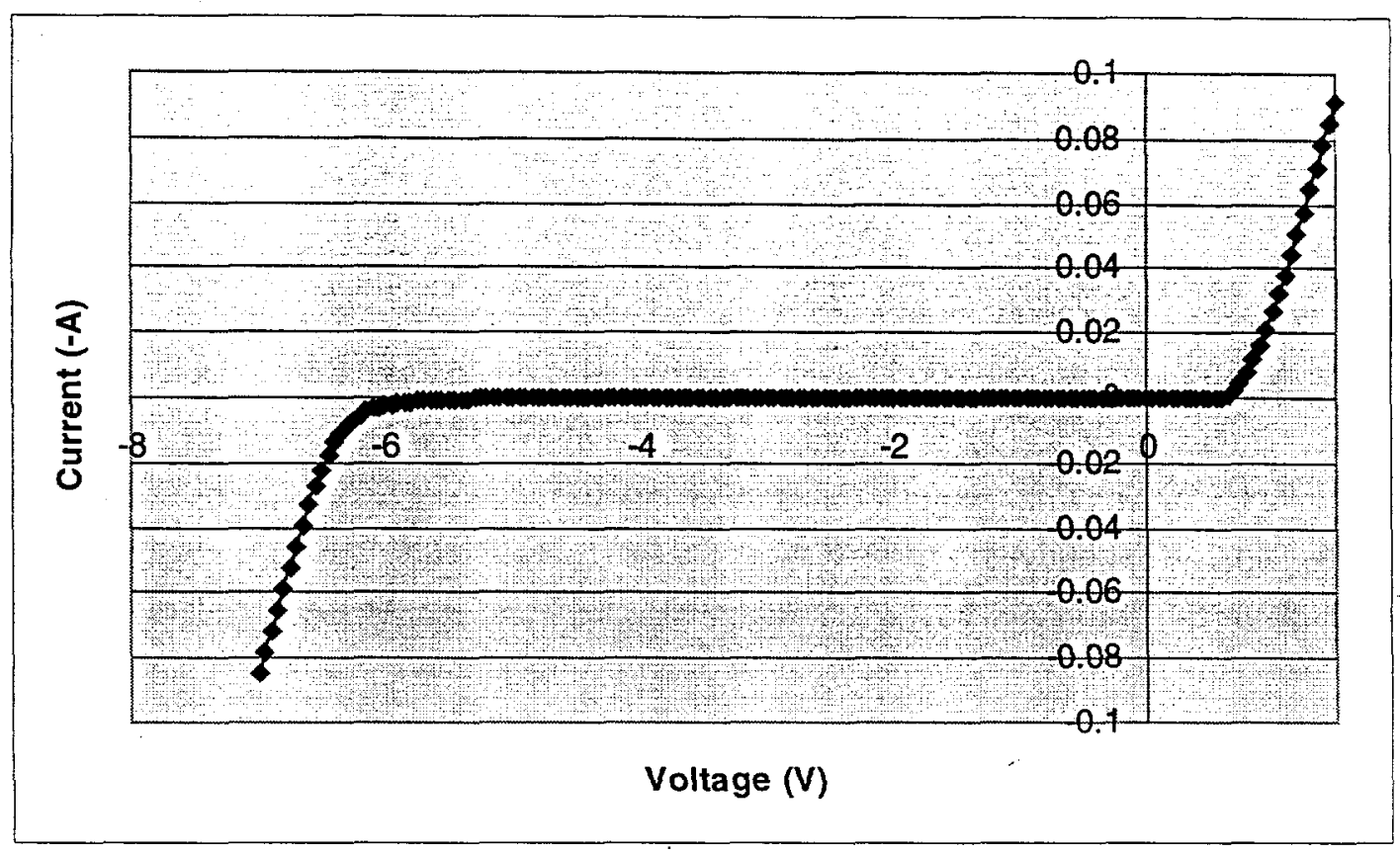

Figure $6 \mathrm{AlGaAsSb}$ diode 